\title{
PERTANIAN
}

\section{PENGARUH PEMUPUKAN KOMPOS BLOTONG DAN PUPUK ORGANIK CAIR ECENG GONDOK TERHADAP INFEKSI ENDOMIKORIZA DAN PRODUKSI TANAMAN SORGUM (Sorghum bicolor (L.) Moench) PADA LAHAN PASIR PANTAI PASEBAN KABUPATEN JEMBER}

\author{
Effect of Fertilizing Blotong Compost and Organic Liquid Fertilizer of Eichhornia crassipes on \\ Endomycorrhizal Infection and Sorghum (Sorghum bicolor (L.) Moench) Plant \\ Production on Sandy Land of Jember Paseban Beach
}

\section{Andina Dwi Pramesti* dan Bambang Hermiyanto}

\author{
Program Studi Agroteknologi, Fakultas Pertanian, Universitas Jember \\ Jalan Kalimantan No. 37 Kampus Tegalboto, Sumbersari, Jember, 68121 \\ *E-mail: andinadwi1012@,gmail.com
}

\begin{abstract}
Sandy land has a considerable potential to resolve the problem of the narrowing area of agricultural land in Indonesia. Improvement of sandy land quality which belongs to the marginal land is necessary in order to increase its productivity, for example through the addition of compost and organic liquid fertilizer. This research aims to know the effect of blotong compost and organic liquid fertilizer of Eichhornia crassipes to endomycorrhizal infection and the production of sorghum plants. The experimental design used was factorial completely randomized block design with 2 factors and 3 replicates. The first factor was dose of blotong compost which consists of 3 levels, i.e. 0, 20, and 40 tons blotong compost /ha. The second factor was concentration of the organic liquid fertilizer of Eichhornia crassipes consists of 4 levels, i.e. 0, 10, 25, and $40 \%$ of the organic liquid fertilizer of Eichhornia crassipes. Further data obtained were analyzed using ANOVA, followed by Duncan Multiple Range Test (DMRT) for significantly different data. The results showed that the application of blotong compost increase soil Corganic, total soil microorganisms, plant height and lowering endomycorrhizal infection. Optimal fertilizing compost blotong dose is 40 tons/ha. The application of organic liquid fertilizer of Eichhornia crassipes increase the total soil microorganisms with optimal concentration of $40 \%$, as well as reducing endomycorrhizal infection. The combination treatment of 20 tons of compost blotong/ha and 10\% organic liquid fertilizer of Eichhornia crassipes already enhance the growth and production of sorghum, but the maximum growth and plant production is achieved with the addition of 40 tons of compost blotong/ha and $40 \%$ organic liquid fertilizer of Eichhornia crassipes.

Keywords: Root infection, sandy land, blotong, Eichhornia crassipes, sorghum
\end{abstract}

\section{ABSTRAK}

Lahan pasir pantai memiliki potensi cukup besar untuk mengatasi masalah semakin menyempitnya luasan lahan pertanian di Indonesia. Perbaikan kualitas lahan pasir pantai yang termasuk ke dalam lahan marginal sangat diperlukan agar dapat meningkatkan produktivitasnya, misalnya melalui penambahan pupuk kompos dan pupuk organik cair (POC). Penelitian ini bertujuan untuk mengetahui pengaruh pemupukan kompos blotong dan POC eceng gondok terhadap infeksi endomikoriza dan produksi tanaman sorgum. Penelitian ini menggunakan rancangan acak kelompok (RAK) dengan 2 faktor dan 3 ulangan. Faktor pertama yaitu dosis kompos blotong yang terdiri atas 3 taraf yaitu 0, 20, dan 40 ton kompos blotong/ha. Faktor kedua yaitu konsentrasi POC eceng gondok yang terdiri atas 4 taraf yaitu 0, 10, 25, dan 40\% POC eceng gondok. Data dianalisis menggunakan ANOVA. Apabila antar perlakuan berbeda nyata maka dilakukan uji lanjut menggunakan Duncan Multiple Range Test (DMRT). Hasil penelitian menunjukkan bahwa pemberian blotong dapat meningkatkan C-organik tanah, total mikroorganisme tanah, tinggi tanaman, serta menurunkan infeksi endomikoriza. Dosis pemupukan kompos blotong yang optimal adalah 40 ton/ha. Pemberian pupuk organik cair eceng gondok dapat meningkatkan total mikroorganisme tanah dibanding kontrol dengan konsentrasi optimal 40\%, serta menurunkan infeksi endomikoriza. Kombinasi perlakuan 20 ton kompos blotong/ha dan 10\% POC eceng gondok sudah dapat meningkatkan pertumbuhan dan produksi tanaman sorgum, namun pertumbuhan dan produksi tanaman maksimum dicapai pada perlakuan penambahan 40 ton kompos blotong/ha dan $40 \%$ POC eceng gondok.

Kata kunci: Infeksi endomikoriza, tanah pasir pantai, blotong, eceng gondok, sorgum.

How to citate: Pramesti, A. D. dan H., Bambang. 2019. Pengaruh Pemupukan Blotong dan Pupuk Organik Cair Eceng Gondok Terhadap Infeksi Endomikoriza dan Produksi Tanaman Sorgum (Sorghum bicolor (L.) Moench) Pada Lahan Pasir Pantai Paseban Kabupaten Jember. Berkala Ilmiah Pertanian 2(3): 108-114.

\section{PENDAHULUAN}

Lahan pertanian merupakan salah satu infrastruktur yang menunjang aktivitas pertanian. Ketersediaan lahan pertanian saat ini semakin lama semakin menurun akibat terjadinya alih fungsi lahan dari pertanian ke non pertanian. Setiap tahunnya sekitar 110.000 hektar beralih fungsi menjadi lahan non-pertanian (Kementerian
Agraria dan Tata Ruang). Untuk mencukupi kebutuhan pangan masyarakat Indonesia, maka FAO dan Kementerian Pertanian sejak tahun 2017 melakukan berbagai upaya untuk mengatasi masalah penurunan lahan pertanian yaitu dengan memanfaatkan lahan marginal. Lahan marginal mempunyai karakteristik yang terbatas, baik keterbatasan satu unsur maupun lebih dari satu unsur (Gunadi, 2002). Lahan marginal dikenal oleh masyarakat sebagai lahan 
konversi dengan tingkat kesuburan tanah yang mulai menurun, atau lahan-lahan kritis yang telah diusahakan pengembalian produktivitasnya. Lahan pesisir merupakan daerah daratan di tepi laut yang meliputi pantai dan daratan di dekatnya yang masih terpengaruh oleh aktivitas marine dan memiliki ciri-ciri tanah pasiran. Badan Informasi Geospasial (BIG) menyebutkan bahwa total garis pantai Indonesia mencapai $99.093 \mathrm{~km}$. Tanah pada lahan pesisir pantai memiliki keterbatasan dalam hal tekstur tanah, kemampuan menahan air, kandungan kimia dan bahan organik tanah (Gunadi, 2002). Salah satu upaya untuk mengelola lahan pasir pantai adalah dengan penambahan bahan organik.

Blotong merupakan salah satu limbah yang dihasilkan oleh pabrik gula dalam proses pembuatan gula, yang keluar dalam bentuk padat yang mengandung air dan masih mempunyai temperatur cukup tinggi. Pada tahun 2008, 57 pabrik gula di Indonesia diperkirakan menghasilkan blotong lebih dari satu juta ton (Supari dkk., 2015). Perlunya pengelolaan dengan benar sangat dibutuhkan supaya blotong tersebut tidak mencemari lingkungan. Seperti yang telah dilakukan PG Semboro, limbah blotong yang dihasilkan kemudian dikomposkan dengan cara aerob. Blotong yang telah dikomposkan nantinya dapat digunakan sebagai pupuk organik bagi tanaman. Hal ini karena blotong mengandung beberapa unsur hara yang dibutuhkan saat pertumbuhan tanaman. Dikutip dari penelitian Supari dkk., (2015) diketahui kompos blotong terdiri dari berbagai komposisi yaitu Karbon C (26,5\%), Nitrogen (1,1\%), Nisbah C/N $(25,6)$, Fosfat $(6,1 \%)$, Kalium $(0,5 \%)$, Natrium $(0,1 \%)$ Calsium $(5,7 \%)$, Magnesium $(0,4 \%)$, Besi $(0,2 \%)$, dan Mangan $(0,1 \%)$. Eceng gondok merupakan tumbuhan yang pertumbuhannya sangat cepat dan dianggap sebagai gulma air karena menyebabkan banyak kerugian yaitu berkurangnya produktivitas badan air seperti mengambil ruang, dan unsur hara yang juga diperlukan ikan (Moi dkk., 2015). Eceng gondok ini memiliki kandungan unsur hara yang berpotensi untuk dimanfaatkan sebagai pupuk organic, seperti mengandung bahan organik sebesar 78,47\%, C-organik $21,23 \%$, N total $0,28 \%$, P total $0,0011 \%$, dan $\mathrm{K}$ total $0,016 \%$.

Tanah pasir pantai merupakan tanah yang mengandung sedikit mikroorganisme tanah sehingga produktivitas tanaman menjadi rendah. Salah satu alternatif teknologi untuk membantu pertumbuhan, meningkatkan produktivitas dan kualitas tanaman yang ditanam pada lahan-lahan marjinal yaitu fungi mikoriza (Nurbaity dkk, 2009). Prinsip kerja dari fungi mikoriza ini yaitu menginfeksi sistem perakaran tanaman inang, memproduksi jalinan hifa secara intensif sehingga tanaman yang mengandung mikoriza tersebut akan mampu meningkatkan kapasitas dalam penyerapan unsur hara. Menurut Nurbaity dkk. (2009), pemberian bahan organik dapat meningkatkan keberadaan fungi mikoriza pada tanah karena tersedianya nutrisi serta media untuk tumbuh dan berkembang.

Sorgum (Sorghum bicolor (L.) Moench) merupakan tanaman pangan penting kelima setelah padi, gandum, jagung dan barley (Khairunnisa dkk, 2015). Di Indonesia, sorgum merupakan tanaman sereal pangan ketiga setelah padi dan jagung (Suarni, 2012). Sorgum merupakan tanaman serealia yang dapat tumbuh di daerah yang beriklim panas dan kering. Menurut Khairunnisa dkk. (2015) keuntungan budidaya tanaman sorgum yaitu sorgum memiliki kemampuan untuk tumbuh kembali setelah dilakukan pemangkasan pada batang bawah dalam satu kali tanam dengan hasil yang tidak jauh berbeda dari sebelumnya. Selain itu, budidaya sorgum dapat dilakukan di lahan marginal sesuai pendapat Sirappa (2003) yang menyatakan bahwa tanaman sorgum dapat berproduksi pada lahan marginal, toleran terhadap kekeringan dan genangan air, serta relatif tahan terhadap gangguan hama/penyakit.

\section{BAHAN DAN METODE}

Bahan dan Alat. Bahan yang digunakan selama penelitian yaitu sorgum varietas Super 2, eceng gondok, Effective Microorganism (EM), kompos blotong PG Semboro, media PDA, media PCA, alkohol, spirtus, kapas steril, larutan fisiologis, larutan glukosa $60 \%$, trypan blue, $\mathrm{KOH} 0.1 \mathrm{~N}, \mathrm{HCl} 0.1 \mathrm{~N}$. Alat yang digunakan untuk penelitian selama dilapang seperti cangkul, sabit, meteran, timba. Alat yang digunakan selama di laboratorium yaitu timbangan, $\mathrm{pH}$ meter, mesin penggojog, spektrofotometer, inkubator, autoclave, stirer, micropippete, laminar air flow, mikroskop, saringan metal 60 mesh, 12 mesh, dan 270 mesh.

Rancangan Percobaan. Penelitian ini menggunakan rancangan acak kelompok (RAK) dengan 2 faktor dan 3 ulangan. Faktor pertama yaitu dosis kompos blotong yang terdiri dari 3 taraf yaitu 0 ton/ha (B0), 20 ton/ha (B1), dan 40 ton/ha (B2). Faktor kedua yaitu konsentrasi POC eceng gondok yang terdiri dari 4 taraf yaitu $0 \%$ POC eceng gondok (P0), 10\% POC eceng gondok (P1), $25 \%$ POC eceng gondok (P2), dan $40 \%$ POC eceng gondok (P3). Data yang diperoleh selanjutnya dianalisis menggunakan ANOVA. Apabila antar perlakuan berbeda nyata maka dilakukan uji lanjut menggunakan Duncan Multiple Range Test (DMRT) pada taraf kepercayaan $95 \%$. Parameter pengamatan tanah dilakukan pada saat sebelum tanam serta setelah panen pada saat berumur 120 HST. Pengamatan pertumbuhan tanaman sorgum dilakukan pada saat setelah panen saat berumur 120 HST.

Pembuatan Pupuk Organik Cair Eceng Gondok. Pupuk organik cair dibuat dengan mengikuti Moi dkk. (2015). Eceng gondok yang digunakan diperoleh di wilayah sekitar Kabupaten Jember. Eceng gondok tersebut dipisahkan dari sampah non organik dan kemudian dipotong-potong menjadi bagian yang lebih kecil atau dirajang. Hal ini bertujuan supaya proses fermentasi dapat berlangsung dengan sempurna. Selanjutnya, disiapkan timba yang diisi dengan air sebanyak 5 liter, kemudian ditambahkan EM sebanyak $1000 \mathrm{ml}$ EM ke dalam 5 liter air yang ada di dalam timba, kemudian larutan tersebut diaduk-aduk hingga merata. Setelah itu, larutan EM yang sudah diperlakukan pengenceran dicampurkan dengan tanaman eceng gondok yang sebelumnya telah dirajang. Campuran ini kemudian dituangkan ke dalam drum sebagai tempat berlangsungnya fermentasi dan diutup rapat selama 14 hari. Ciri fermentasi telah selesai yaitu larutan berwarna coklat kehitaman dan tidak berbau serta menghasilkan lindi.

Penanaman. Lahan pasir yang akan digunakan diukur terlebih dahulu untuk memudahkan penanaman yang akan dilakukan, jarak tanam yang digunakan yaitu $75 \times 20 \mathrm{~cm}$ dengan luas bedengan yaitu $3 \mathrm{~m}^{2}$. Lahan yang akan digunakan dilakukan pembersihan lahan dan pembuatan bedengan dengan pemberian blotong sesuai perlakuan kemudian dicampur secara merata. Benih sorgum yang digunakan adalah benih tanaman sorgum varietas Super 2 yang ditanam 5 benih setiap lubang tanam. Pemupukan dilakukan dua kali yaitu pertama bersamaan waktu tanam $(75 \mathrm{~kg}$ urea/ha $+100 \mathrm{~kg} \mathrm{SP}-36 / \mathrm{ha}+50 \mathrm{~kg} \mathrm{KCl} / \mathrm{ha}$ ) di kiri kanan barisan tanaman dengan jarak $\pm 7 \mathrm{~cm}$ dan kedua yaitu dilakukan saat 30 HST ( $75 \mathrm{~kg}$ urea/ha) dengan jarak $\pm 15 \mathrm{~cm}$. Pengaplikasian pupuk organik cair eceng gondok yaitu $100 \mathrm{ml} /$ tanaman pada umur $30 \mathrm{HST}$ dan 60 HST.

Tabel 1. Karakteristik tanah pada lahan pasir pantai Paseban

\begin{tabular}{lccc}
\hline \multicolumn{1}{c}{ Komponen } & Satuan & Nilai & Harkat $(*)$ \\
\hline $\mathrm{pH} \mathrm{H} \mathrm{H}_{2} \mathrm{O}$ & - & 7.29 & Netral \\
$\mathrm{C}$-organik & $\%$ & 0.21 & Sangat Rendah \\
$\mathrm{N}$ total & $\%$ & 0.01 & Sangat Rendah \\
$\mathrm{P}$ tersedia & $\mathrm{ppm}$ & 42.03 & Sangat Tinggi \\
$\mathrm{K}$ tersedia & $\mathrm{cmol}(+) / \mathrm{kg}$ & 14.95 & Sangat Tinggi \\
\hline
\end{tabular}

*Berdasarkan Kriteria Hasil Penelitian Tanah (2005)

Sumber : Laboratorium Kimia Tanah Fakultas Pertanian Universitas Jember

Tabel 2. Karakteristik kompos blotong PG Semboro dan POC eceng gondok

\begin{tabular}{clcc}
\hline Jenis Pupuk & Jenis Analisis & Satuan & Nilai \\
\hline Kompos Blotong & $\mathrm{pH} \mathrm{H}_{2} \mathrm{O}$ & - & 7.09 \\
& C-organik & $\%$ & 3.89 \\
& $\mathrm{~N}$ total & $\%$ & 1.44 \\
& P tersedia & $\mathrm{ppm}$ & 831.80 \\
& K tersedia & $\mathrm{ppm}$ & 167.00 \\
POC Eceng gondok & Asam Humat & $\%$ & 13.60 \\
\hline
\end{tabular}

Sumber : Laboratorium Kimia Tanah Fakultas Pertanian Universitas Jember 


\section{HASIL DAN PEMBAHASAN}

pH tanah. Hasil sidik ragam parameter $\mathrm{pH}$ tanah menunjukkan perbedaan yang tidak nyata dari pemberian perlakuan pemupukan kompos blotong dan pupuk organik cair eceng gondok (Tabel 3). Secara keseluruhan, $\mathrm{pH}$ tanah pasir pantai Paseban meningkat dibandingkan dengan sebelum diberikan perlakuan pemupukan yaitu 7.29. Hal ini menunjukkan bahwa pemberian bahan organik seperti kompos blotong dan pupuk organik cair eceng gondok dapat meningkatkan nilai $\mathrm{pH}$ tanah.

C-organik. C-organik menunjukkan jumlah bahan organik yang ada didalam tanah. Hasil sidik ragam menunjukkan bahwa perlakuan faktor tunggal kompos blotong berbeda nyata terhadap parameter $\mathrm{C}$-organik tanah. Kandungan $\mathrm{C}$-organik terbaik diberikan oleh perlakuan pemupukan 40 ton kompos blotong/ha (B2) sebesar $1.28 \%$ yang berbeda tidak nyata dengan B1 (20 ton kompos blotong/ha) yang menghasilkan C-organik sebesar $1.25 \%$ (Grafik 1). Kandungan C-organik pada analisis awal sebelum diberikan perlakuan menunjukkan bahwa tanah pasir pantai Paseban memiliki C-organik sebesar $1.03 \%$ dan termasuk dalam kategori rendah. Pemberian pemupukan kompos blotong pada tanah tersebut, dapat meningkatkan C-organik didalam tanah namun masih tergolong dalam kategori rendah.

Total mikroorganisme tanah. Mikroorganisme didalam tanah memiliki peran yang sangat penting. Diketahui bahwa total mikroorganisme tanah tertinggi ditunjukkan pada perlakuan B2 (40 ton kompos blotong/ha) sebesar $7.92 \times 10^{6} \mathrm{CFU} /$ gram yang berbeda nyata dengan perlakuan lainnya (Grafik 2). Konsentrasi POC eceng gondok $40 \%$ (P3) memberikan hasil yang tertinggi yaitu $7.84 \times 10^{6}$ $\mathrm{CFU} /$ gram dan berbeda nyata dengan perlakuan lainnya (Grafik 3).

Infeksi endomikoriza. Infeksi endomikoriza merupakan salah satu parameter pengamatan dimana digunakan untuk mengetahui terjadinya kolonisasi antara fungi mikoriza dengan akar tanaman inang yaitu tanaman sorgum. Infeksi tertinggi ditunjukkan oleh perlakuan B0 (0 ton kompos blotong/ha) sebesar 29.72\% yang tergolong dalam kategori sedang yang berbeda nyata dengan perlakuan lainnya (Grafik 4). Infeksi tertinggi ditunjukkan pada perlakuan dengan konsentrasi POC eceng gondok $0 \%$ (P0) sebesar $31.85 \%$ yang tergolong dalam kategori sedang yang berbeda nyata dengan perlakuan P1, P2 dan P3 (Grafik 5).

Tinggi tanaman. Perlakuan terbaik terhadap tinggi tanaman yaitu pada perlakuan B2 (40 ton kompos blotong/ha) dengan tinggi tanaman hingga $244.16 \mathrm{~cm}$ yang berbeda tidak nyata dengan B1 (20 ton kompos blotong/ha) dengan tinggi tanaman $237 \mathrm{~cm}$ (Grafik 6).

Luas daun per tanaman. luas daun terbesar dihasilkan oleh tanaman dengan perlakuan B2P3 (40 ton kompos blotong/ha dan $40 \%$ POC eceng gondok) sebesar $1269 \mathrm{~cm} 2$ yang berbeda tidak nyata dengan perlakuan B2P2 (40 ton kompos blotong/ha dan 25\% POC eceng gondok) sebesar $1193.6 \mathrm{~cm} 2$ dan berbeda nyata dengan perlakuan lainnya (Tabel 5).

Berat basah dan berat kering tanaman. Berat basah tanaman menggambarkan kemampuan tanaman dalam menyerap air (Apzani dkk, 2017). Perlakuan yang memberikan respon berat basah tertinggi yaitu B2P3 (40 ton kompos blotong/ha dan 40\% POC eceng gondok) yang berbeda nyata dengan perlakuan yang lainnya (Tabel 5). Berat kering tanaman sebagai parameter penelitian digunakan untuk mengetahui besarnya asimilat yang dihasilkan oleh tanaman. Berat kering tanaman tertinggi yang dihasilkan adalah dari kombinasi kompos blotong 40 ton/ha dengan $40 \%$ POC eceng gondok (B2P3) yaitu dengan rataan sebesar 337.84 gram yang berbeda nyata dengan perlakuan lainnya yang dapat dilihat pada tabel 5 .

Berat malai per tanaman. Berat malai tertinggi yang dihasilkan oleh tanaman adalah pada perlakuan B2P3 (40 ton kompos blotong/ha dan $40 \%$ POC eceng gondok) yang berbeda sangat nyata dengan perlakuan lainnya yaitu sebesar 71.6 gram (Tabel 5).

Berat 1000 biji. Hasil sidik ragam menunjukkan perlakuan kombinasi pemupukan kompos blotong dan POC eceng gondok memberikan pengaruh yang tidak nyata terhadap parameter berat 1000 biji. Hal ini diduga karena intensitas dan jumlah air yang diberikan pada saat penyiraman sama rata untuk semua perlakuan pada penelitian, sehingga pengangkutan asimilat ke bagian biji tidak terhambat.

Hasil penelitian menunjukkan secara keseluruhan $\mathrm{pH}$ tanah pantai Paseban meningkat dibandingkan dengan sebelum diberikan perlakuan pemupukan. Menurut Nariratih dkk. (2013) pemberian bahan organik dapat meningkatkan $\mathrm{pH}$ tanah disebabkan karena bahan organik memiliki kemampuan mengkhelat logam $\mathrm{Al}^{3+}$ sehingga tidak terjadi reaksi hidrolisis $\mathrm{Al}^{3+}$ yang dapat menghasilkan 3 ion $\mathrm{H}^{+}$yang dapat mengasamkan tanah. Fikdalillah dkk. (2016) menambahkan bahwa nilai $\mathrm{pH}$ tanah meningkat diduga disebabkan oleh adanya asam-asam organik yang dikandung oleh pupuk organik yang dapat bereaksi dengan $\mathrm{Al}^{3+}$ dalam larutan tanah yang merupakan penyumbang ion $\mathrm{H}^{+}$atau penyebab kemasaman tanah.

Tabel 3. Pengaruh pemupukan blotong dan POC eceng gondok terhadap $\mathrm{pH}$ tanah

Kombinasi Perlakuan

Blotong dan POC eceng gondok

\begin{tabular}{ll} 
B0P0 & 7.29 \\
B0P1 & 7.32 \\
B0P2 & 7.34 \\
B0P3 & 7.28 \\
B1P0 & 7.45 \\
B1P1 & 7.44 \\
B1P2 & 7.57 \\
B1P3 & 7.50 \\
B2P0 & 7.37 \\
B2P1 & 7.33 \\
B2P2 & 7.49 \\
B2P3 & 7.29 \\
\hline
\end{tabular}

Keterangan: Hasil anova menunjukkan hasil tidak berbeda nyata maka tidak dilanjutkan pada uji DMRT pada taraf kepercayaan 95\%

Menurut Rajiman (2014), penggunaan bahan pembenah tanah seperti blotong pada tanah pasir pantai dapat meningkatkan kandungan C-organik, $\mathrm{pH}$, serta hara N, P, K. Sumbangan C-organik yang terdapat dalam blotong disebabkan oleh dekomposisi pupuk blotong yang melepaskan sejumlah senyawa karbon (C) sebagai penyusun utama dari bahan organik itu sendiri. Lahan pasir pantai memiliki kemampuan untuk menyediakan udara yang berlebihan sehingga hal tersebut berakibat pada oksidasi bahan organik yang cepat dan laju perombakan bahan organik yang sangat besar (Hasibuan, 2015). Nariratih dkk. (2013) menambahkan bahwa Corganik yang rendah di dalam tanah dapat pula disebabkan oleh erosi, evapotranspirasi serta terangkut panen.

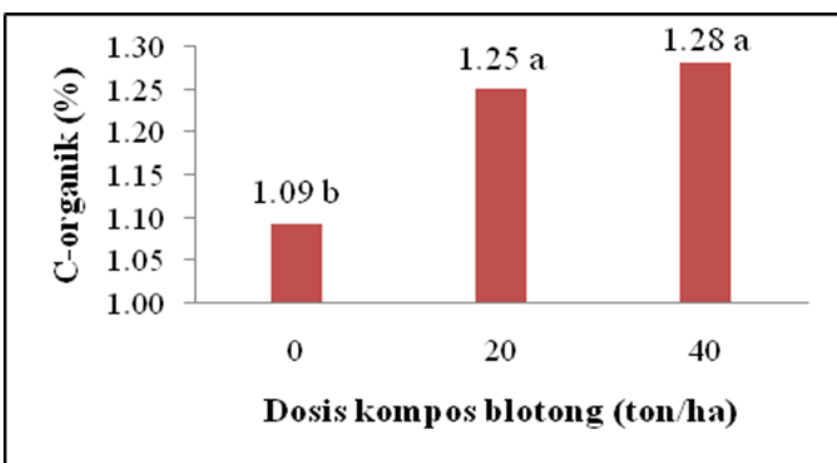

Grafik 1. Diagram pengaruh kompos blotong terhadap C-organik tanah

Pemberian bahan organik (jaringan tanaman) dapat meningkatkan kegiatan biologi tanah seiring dengan meningkatnya jumlah mikroorganisme didalam tanah (Karnilawati dkk, 2016). Hal ini dapat disebabkan oleh kandungan $\mathrm{N}$ yang ada dalam pupuk organik yang digunakan oleh sel-sel mikrobia untuk memperbanyak diri sehingga hal ini menyebabkan mikroorganisme didalam tanah meningkat. Tikhonov et al. dalam Santi (2016), juga menyebutkan bahwa asam humat yang terkandung dalam pupuk organik cair eceng gondok dapat dijadikan sebagai sumber karbon serta 
membantu menyediakan nutrisi yang cukup bagi pertumbuhan mikroorganisme didalam tanah. Pemberian bahan organik ke dalam tanah berkorelasi positif dan erat terhadap populasi fungi tanah, dimana diduga pengaruh yang diberikan oleh bahan organik terhadap populasi fungi tanah disebabkan karena kandungan Corganik tanah yang meningkat karena pemberian bahan organik (Tanzil dkk, 2015).

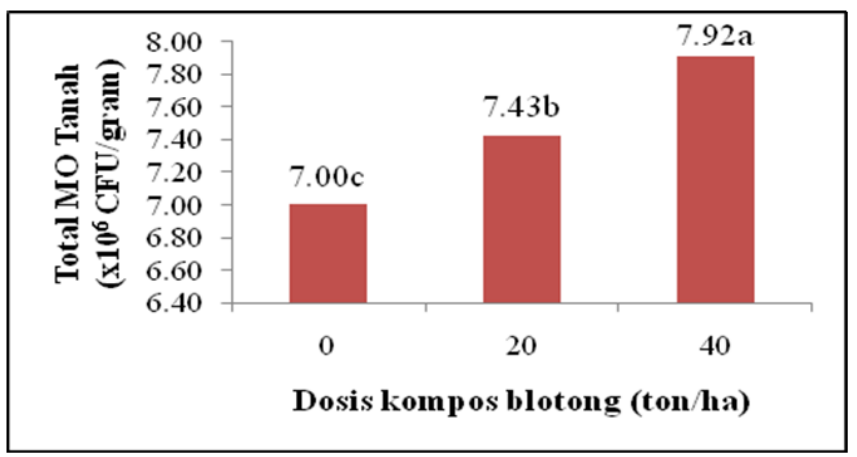

Grafik 2. Diagram pengaruh perlakuan kompos blotong terhadap total mikroorganisme tanah

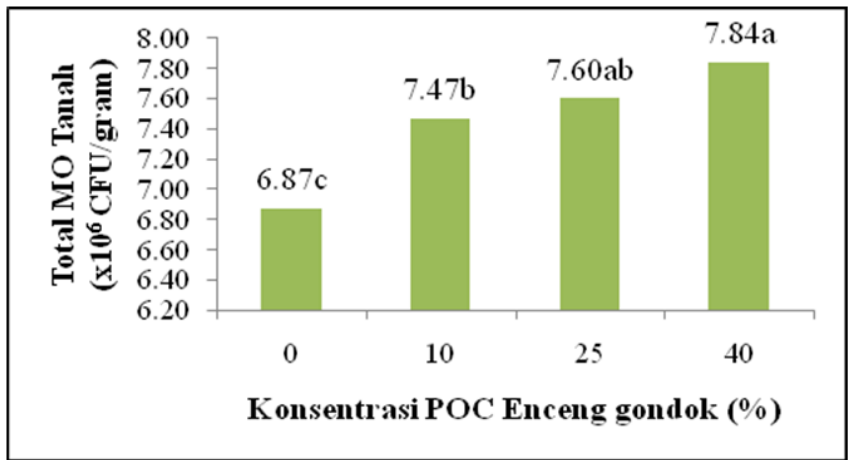

Grafik 3. Diagram pengaruh perlakuan POC eceng gondok terhadap total mikroorganisme tanah

Bahan-bahan humat mengandung sejumlah ragam gugus hidroksil, namun untuk karakterisasi asam humat umumnya hanya tiga jenis $\mathrm{OH}$ yang dibedakan yaitu hidroksi total yang merupakan gugus $\mathrm{OH}$ yang berkaitan dengan semua gugus fungsional, seperti fenol, alkohol, enol, serta hidrokinon, gugus $\mathrm{OH}$-fenolik yaitu $\mathrm{OH}$ yang terikat pada lingkar benzena serta gugus $\mathrm{OH}$-alkoholik yaitu $\mathrm{OH}$ yang berikatan dengan gugus alkoholik. Ciri-ciri dari fraksi asam humat adalah resisten terhadap degradasi mikroba, berkemampuan dalam membentuk kompleks dengan ion logam, dan berinteraksi dengan mineral liat (Grinhut et al., 2007).

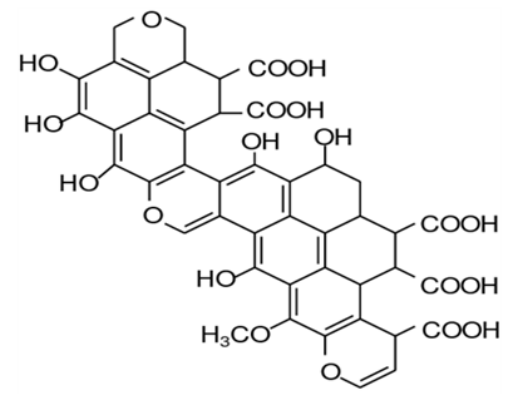

Gambar 1. Struktur asam humat

Menurut Nurhalimah dkk. (2014), tanah-tanah yang mengandung nitrogen serta fosfat dalam jumlah yang tinggi maka jumlah mikoriza yang berada dalam tanah tersebut rendah. Luqman dkk. (2015) menambahkan bahwa pada dasarnya fungsi mikoriza bagi tanaman adalah sebagai pembantu dalam penyerapan unsur hara bagi tanaman, tidak hanya unsur $\mathrm{P}$ saja. Selain membantu penyerapan unsur $\mathrm{P}$, adanya mikoriza didalam tanah juga dapat membantu penyerapan unsur-unsur hara lainnya seperti N, K, serta unsur lainnya (Othira et al., 2012) seperti unsur $\mathrm{Ca}, \mathrm{Cu}, \mathrm{Mg}, \mathrm{S}, \mathrm{Fe}$, dan Zn (Fulekar et al., 2017). Tanaman yang kandungan unsur N dan P nya meningkat disebabkan karena akar yang terinfeksi oleh mikoriza dimana akar yang bermikoriza dapat menyerap unsur hara dalam bentuk terikat dan tidak tersedia dalam tanah (Fulekar et al., 2017). Pada penelitian Nasr et al. (2013), infeksi yang terjadi pada akar sorgum dapat meningkatkan penyerapan unsur $\mathrm{N}$ dan P. Caris et al. (1998) dalam Hermawan dkk. (2015) menyebutkan bahwa hifa mikoriza dapat menjangkau tanah yang tidak terjangkau akar tanaman dan melalui hifanya unsur hara dapat ditransfer ke dalam tanaman. Adanya hifa dianggap berfungsi sebagai rambut akar (rhizomorf) untuk menyerap seluruh hara tanah dan air. Selain hal tersebut, mikoriza pada akar tanaman akan menambah luas permukaan absorbsi unsur hara dan air.

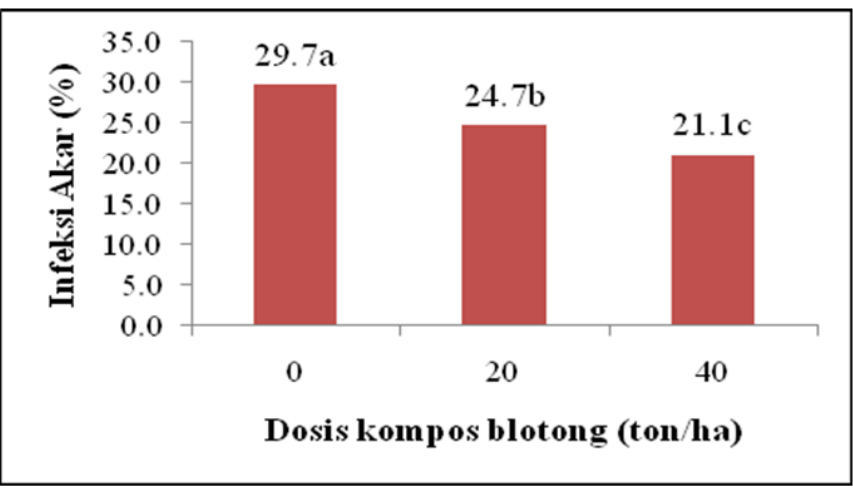

Grafik 4. Diagram pengaruh blotong terhadap infeksi endomikoriza

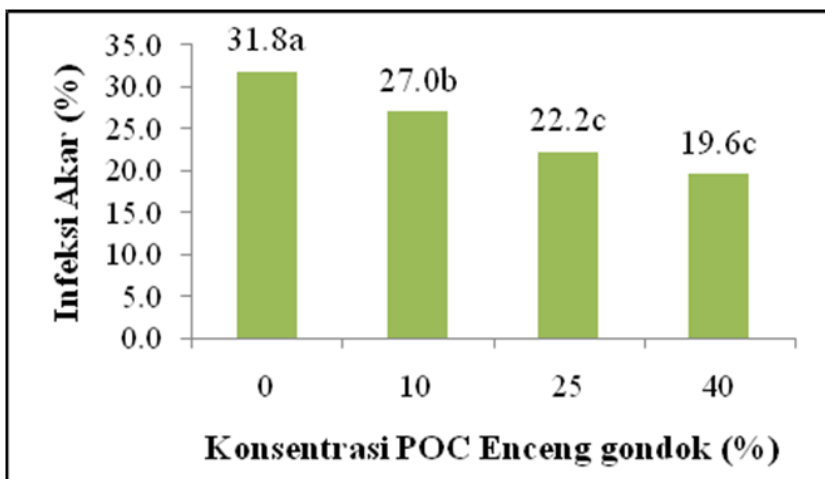

Grafik 5. Diagram pengaruh POC eceng gondok terhadap infeksi endomikoriza

Pada penelitian ini fungi mikoriza yang ditemukan diduga merupakan fungi mikoriza dengan genus acaulospora. Proses perkembangan spora acaulospora berawal dari ujung hifa (subtending hyphae) yang membesar seperti spora yang disebut hyphal terminus. Di antara hyphal terminus dan subtending hypae akan muncul bulatan kecil yang semakin lama semakin membesar dan terbentuk spora. Bentuk spora acaulospora ada yang bulat dan bulat agak lonjong dan spora berwarna coklat tua dan kuning kecoklatan (Nurhalimah dkk., 2014).

Perkembangan mikoriza diawali sejak berada di tanah dalam bentuk spora hingga dapat menginfeksi akar tanaman. Perkembangan suatu infeksi mikoriza dimulai dengan pembentukan apresorium pada permukaan akar oleh hifa eksternal yang berasal dari spora mikoriza dalam tanah. Hifa dari apresorium menembus sel-sel epidermis dan menjalar di antara sel atau dalam sel sepanjang akar korteks. Akar bermikoriza membentuk jaringan hifa luar (eksternal) yang lepas, yang merupakan kelanjutan dari hifa dalam (internal). Hifa yang berada di dalam jaringan akar tanaman yang terinfeksi mikoriza terdiri atas hifa yang tidak bercabang yang terletak di ruangan antara sel. Selain itu terdapat pula hifa intraseluler yang membengkok menjadi bulat atau bulat memanjang yang disebut vesikel (Prihastuti, 2007). Prinsip kerja dari mikoriza ini yaitu menginfeksi sistem perakaran tanaman inang, memproduksi jalinan hifa secara intensif sehingga tanaman yang mengandung mikoriza tersebut akan mampu meningkatkan kapasitas dalam penyerapan unsur hara. Pada dasarnya fungi 
mikoriza diperlukan tanaman untuk menyerap P yang masih terikat dengan unsur lain sehingga menjadi P-tersedia bagi tanaman. Fosfat merupakan unsur hara makro yang dibutuhkan oleh tanaman serta berpengaruh terhadap keberadaan fungi mikoriza di dalam tanah dimana hifa mikoriza membantu dalam penyerapan fosfat di dalam tanah. Kandungan $\mathrm{P}$ yang rendah pada tanaman dapat menyebabkan kandungan fosfolipid pada tanaman juga menurun sehingga permeabilitas membran sel akar meningkat yang berakibat pada peningkatan kolonisasi fungi mikoriza (Prihastuti, 2007). Fosfat yang telah diserap oleh hifa eksternal akan segera diubah menjadi senyawa polifosfat dan dipindahkan ke dalam hifa internal dan arbuskul. Di dalam arbuskul, senyawa polifosfat dipecah menjadi fosfat organik yang kemudian dilepaskan ke sel tanaman inang (Nurhalimah dkk, 2014).
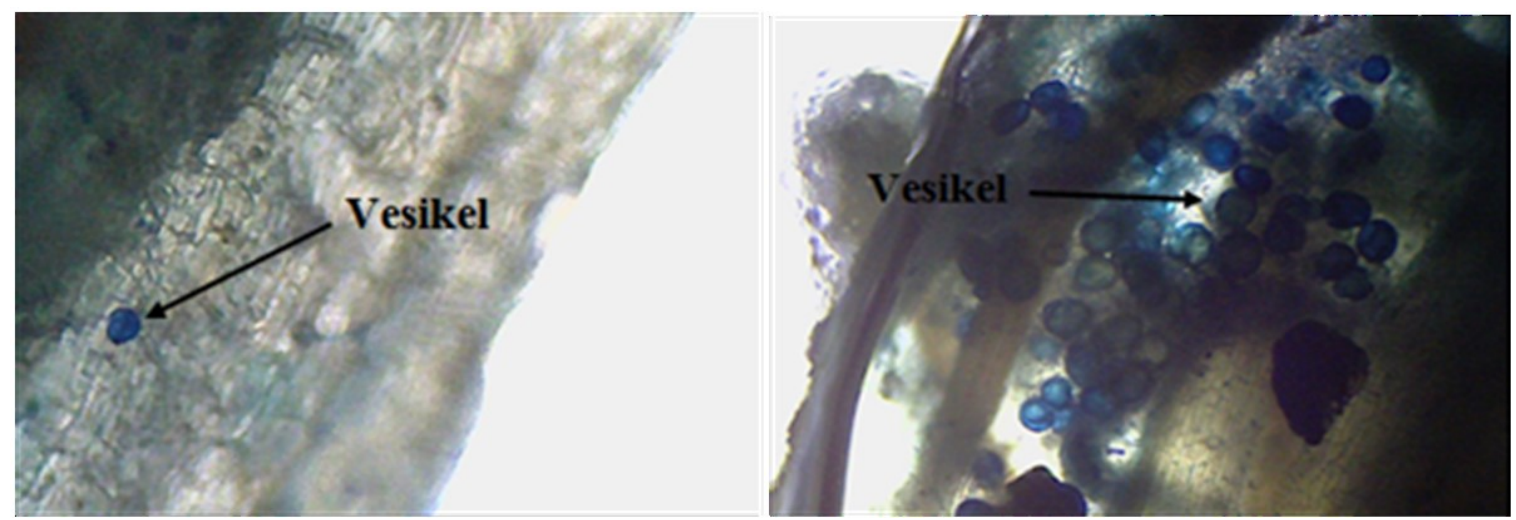

Gambar 2. Infeksi endomikoriza pada tanaman sorgum

Menurut Moi dkk. (2015), pupuk organik cair eceng gondok mengandung $\mathrm{N}$ total $0.28 \%$, sedangkan kompos blotong $\mathrm{PG}$ Semboro memiliki kandungan $\mathrm{N}$ total $1.44 \%$. Penelitian Moi dkk. (2015) dan Ibrahim et al. (2011) juga menyebutkan bahwa semakin banyak hara $\mathrm{N}$ yang diterima oleh tanaman melalui pupuk organik maka semakin tinggi pula tanaman, karena bahan organik yang ada pada pupuk organik telah diuraikan oleh mikroorganisme sehingga membantu menyediakan $\mathrm{N}$ bagi tanaman. Kandungan $\mathrm{N}$ pada pupuk organik membentuk klorofil dan protein. Apabila kekurangan protein dapat mempengaruhi pertumbuhan sel vegetatif, sementara itu apabila tanaman kekurangan klorofil maka akan menyebabkan berkurangnya kemampuan tanaman untuk memproduksi karbohidrat. Tersedianya unsur hara $\mathrm{N}$ dalam jumlah yang cukup pada saat pertumbuhan vegetatif, maka proses fotosintesis akan berjalan aktif, sehingga pembelahan, pemanjangan dan diferensiasi sel akan berjalan dengan baik. Penambahan bahan organik pada tanah merupakan salah satu teknik pengolahan tanah untuk memperbaiki sifat-sifat tanah, dimana penambahan bahan organik menurut Agung et al. (2014) dapat memperbaiki perkembangan akar tanaman sehingga dapat menyerap unsur hara lebih baik dan mampu meningkatkan pertumbuhan tanaman. Pambudi dkk. (2017) menyatakan bahwa penyerapan unsur hara yang baik dapat mengakibatkan pertumbuhan tanaman menjadi optimal, sehingga menghasilkan berat segar dan bobot kering lebih tinggi.

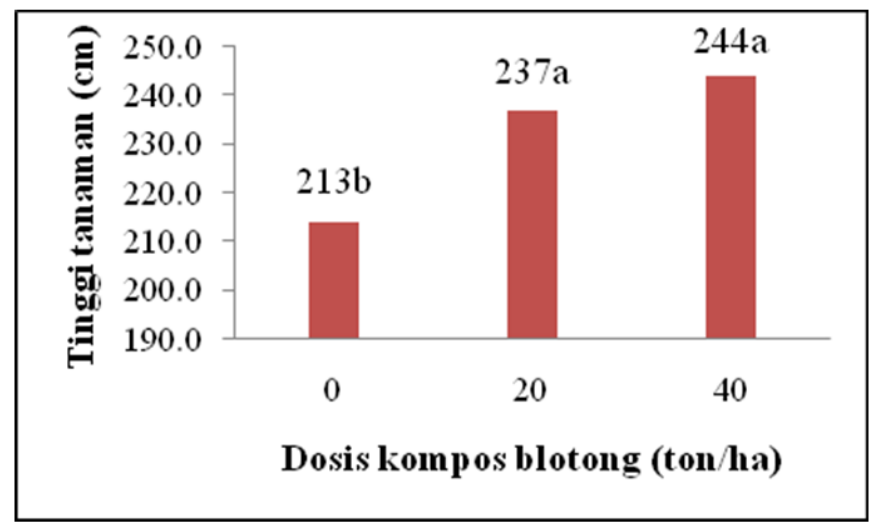

Grafik 6. Diagram pengaruh kompos blotong terhadap tinggi tanaman sorgum

Tabel 5. Pengaruh perlakuan kompos blotong dan POC eceng gondok terhadap berat basah, berat kering dan berat malai/tanaman

\begin{tabular}{|c|c|c|c|c|}
\hline $\begin{array}{c}\text { Kombinasi Perlakuan Kompos } \\
\text { Blotong dan POC eceng gondok }\end{array}$ & $\begin{array}{c}\text { Luas daun } \\
\left(\mathrm{cm}^{2}\right)\end{array}$ & $\begin{array}{c}\text { Berat basah } \\
\text { tanaman } \\
(\text { gram })\end{array}$ & $\begin{array}{c}\text { Berat kering } \\
\text { tanaman } \\
(\text { gram })\end{array}$ & $\begin{array}{c}\text { Berat } \\
\text { malai/tanaman } \\
\text { (gram })\end{array}$ \\
\hline B0P0 & $481.4 \mathrm{f}$ & $154.5 \mathrm{~g}$ & $73.1 \mathrm{f}$ & $17.2 \mathrm{f}$ \\
\hline B0P1 & $550.3 \mathrm{ef}$ & $154.9 \mathrm{~g}$ & $93.7 \mathrm{f}$ & $23.4 \mathrm{ef}$ \\
\hline B0P2 & $645.6 \mathrm{de}$ & $157.6 \mathrm{~g}$ & $83.7 \mathrm{f}$ & $20.8 \mathrm{f}$ \\
\hline B0P3 & $766.1 \mathrm{c}$ & $172.0 \mathrm{fg}$ & $108.4 \mathrm{ef}$ & $39.7 \mathrm{c}$ \\
\hline B1P0 & $453.2 \mathrm{f}$ & $236.1 \mathrm{efg}$ & $105.8 \mathrm{ef}$ & $28.8 \mathrm{de}$ \\
\hline B1P1 & $672.5 \mathrm{~cd}$ & $285.5 \mathrm{de}$ & $195.3 \mathrm{~cd}$ & $33.3 \mathrm{~d}$ \\
\hline B1P2 & $739.2 \mathrm{~cd}$ & $255.1 \mathrm{def}$ & $154.9 \mathrm{de}$ & $42.4 \mathrm{c}$ \\
\hline B1P3 & $998.0 \mathrm{~b}$ & $473.9 \mathrm{~b}$ & $267.1 \mathrm{~b}$ & $55.3 \mathrm{~b}$ \\
\hline B2P0 & $540.9 \mathrm{f}$ & $344.0 \mathrm{~cd}$ & $180.0 \mathrm{~cd}$ & $31.2 \mathrm{~d}$ \\
\hline B2P1 & $1043.4 \mathrm{~b}$ & $286.4 \mathrm{de}$ & $182.0 \mathrm{~cd}$ & $53.9 \mathrm{~b}$ \\
\hline B2P2 & $1193.6 \mathrm{a}$ & $401.1 \mathrm{bc}$ & $231.0 \mathrm{bc}$ & $56.8 \mathrm{~b}$ \\
\hline B2P3 & $1269.0 \mathrm{a}$ & $685.7 \mathrm{a}$ & $337.8 \mathrm{a}$ & $71.6 \mathrm{a}$ \\
\hline
\end{tabular}

Keterangan: Angka pada kolom yang sama diikuti oleh huruf berbeda menunjukkan beda nyata menurut uji DMRT pada taraf kepercayaan 95\%. 
Menurut Halifah dkk. (2014) luas daun yang besar memungkinkan terjadinya laju fotosintesis yang lebih besar karena memungkinkan untuk penangkapan cahaya dan $\mathrm{CO}_{2}$ yang lebih efektif sehingga hal ini menyebabkan karbohidrat yang dihasilkan menjadi lebih banyak dan disimpan pada bagian-bagian tertentu tanaman atau digunakan untuk proses pertumbuhan tanaman selanjutnya. Asam humat yang ada dalam POC eceng gondok dapat meningkatkan kandungan klorofil pada daun, sehingga laju fotosintesis pada tanaman meningkat, dan proses metabolisme tanaman dapat berjalan dengan lebih baik (Victolika dkk, 2014). Fotosintesis merupakan proses penting dalam tanaman, karena fotosintesis dapat menghasilkan karbohidrat yang dapat digunakan untuk pertumbuhan tanaman. Dengan meningkatnya kandungan karbohidrat pada daun tanaman maka pertumbuhan tanaman juga akan meningkat.

Menurut Fikdalillah dkk. (2016) dan Agung et al. (2014) tanah yang ke dalamnya diaplikasikan bahan organic menyebabkan aerasi serta drainase tanah akan menjadi lebih baik, kandungan air di dalam tanah dapat dipertahankan dengan lebih baik dan menurunkan bobot isi tanah sehingga tanah lebih gembur. Hal ini memungkinkan akar untuk tumbuh dan berkembang dengan lebih baik. Pambudi dkk. (2017) menyatakan bahwa penyerapan unsur hara yang baik dapat mengakibatkan pertumbuhan tanaman menjadi optimal sehingga mengakibatkan pertumbuhan dan perkembangan tanaman menjadi lebih baik dan menghasilkan berat segar dan bobot kering lebih tinggi. Menurut Subba (1995) dalam Apzani dkk. (2017) dan Khaled and Fawy (2011), ketersediaan unsur fosfor sebagai hasil pelepasan hara oleh khelat asam humat yang berasal dari hasil fermentasi bahan organik dapat menyebabkan peningkatan berat tanaman. Keberadaan unsur fosfor bagi tanaman sangatlah penting mengingat fosfor berperan dalam translokasi asimilat, menyimpan dan mentransfer energi dari fotosintat yang digunakan dalam proses metabolisme.

\section{KESIMPULAN}

Hasil penelitian menunjukkan bahwa pemberian blotong dapat meningkatkan $\mathrm{C}$-organik tanah, total mikroorganisme tanah, tinggi tanaman, serta menurunkan infeksi endomikoriza. Dosis pemupukan kompos blotong yang optimal adalah 40 ton/ha. Pemberian pupuk organik cair eceng gondok dapat meningkatkan total mikroorganisme tanah dibanding kontrol dengan konsentrasi optimal $40 \%$, serta menurunkan infeksi endomikoriza. Kombinasi perlakuan 20 ton kompos blotong/ha dan 10\% POC eceng gondok sudah dapat meningkatkan pertumbuhan dan produksi tanaman sorgum, namun pertumbuhan dan produksi tanaman maksimum dicapai pada perlakuan penambahan 40 ton kompos blotong/ha dan $40 \%$ POC eceng gondok.

\section{DAFTAR PUSTAKA}

Agung, I. M. S., I. K. Sardiana., I. W. Diara and I. O. Nurjaya. 2014. Residual Effect of Compost on Ethanol Production of Sweet Soghum [Sorghum bicolor (L.) Moench] Varieties and Soil Organic Carbon at Dryland Farming Area in Bali, Indonesia. Biology, Agriculture and Healthcare, 4(13):96-102.

Apzani, W., H. A. W. Wardhana, Baharuddin dan Z. Arifin. 2017. Efektivitas Pupuk Organik Cair Eceng Gondok (Eichhornia crassipes) Fermentasi Trichoderma spp. Terhadap Pertumbuhan Selada (Lactuca sativa L.). Sangkareang Mataram, 3(3):1-9.

Fikdalillah, M. Basir dan I. Wahyudi. 2016. Pengaruh Pemberian Pupuk Kandang Sapi Terhadap Serapan Fosfor Dan Hasil Tanaman Sawi Putih (Brassica pekinensis) Pada Entisols Sidera. Agrotekbis, 4(5):491-499.

Fulekar, J., B. Pathak and M. H. Fulekar. 2017. Development of Mycorrhizosphere Using Sorghum bicolor for Rhizosphere
Biormediation. Current Research and Academic Review, $5(6): 42-48$.

Gunadi, S. 2002. Teknologi Pemanfaatan Lahan Marginal Kawasan Pesisir. Teknologi Lingkungan, 3(3):232-236.

Hermawan, H., A. Muin dan R. S. Wulandari. 2015. Kelimpahan Fungi Mikoriza Arbuskula (FMA) Pada Tegakan Ekaliptus (Eucalyptus pellita) Berdasarkan Tingkat Kedalaman Di Lahan Gambut. Hutan Lestari, 3(1):124-132.

Ibrahim, I. E., A. E. Hassan, E. A. Elasha and S. Elagab. 2011. Effect of Organic Manures on Yield and Yield Components of Rain-fed Sorghum in the Gedarif State. Science and Technology, 12(4):48-57.

Karnilawati, Yusnizar dan Zuraida. 2016. Pengaruh Jenis Dan Dosis Bahan Organik Pada Entosil Terhadap Total Mikroorganisme Tanah Dan Aktivitas Mikroorganisme (Respirasi) Tanah Pada Rhizosfer Kedelai. Prosiding Seminar Nasional Biotik. 266-272.

Khairunnisa, R. R. Lahay, dan T. Irmansyah. 2015. Respons Pertumbuhan dan Produksi Tanaman Sorgum (Sorghum bicolor (L.) Moench) terhadap Pemberian Mulsa dan Berbagai Metode Olah Tanah. Agroekoteknologi, 3(1):359366.

Khaled, H. and H. A. Fawy. 2011. Effect of Different Levels of Humic Acids on the Nutrient Content, Plant Growth, and Soil Properties under Conditions of Salinity. Soil \& Water Res. 6(1):21-29.

Luqman, Rizalinda dan S. Khotimah. 2015. Fungi Mikoriza Vesikular Arbuskular (MVA) pada Rhizosfer Tanaman Langsat (Lansium domesticum Corr.) di Lahan Gambut. Protobiont, 4(3):89-97.

Moi, A. R., D. Pandingan, P. Siahaan, dan A. M. Tangapo. 2015. Pengujian Pupuk Organik Cair dari Eceng Gondok (Eichhornia crassipes) terhadap Pertumbuhan Tanaman Sawi (Brassica juncea). MIPA UNSRAT, 4(1): 15-19.

Nariratih, I., M.M.B. Damanik dan G. Sitanggang. 2013. Ketersediaan Nitrogen Pada Tiga Jenis Tanah Akibat Pemberian TigaBahan Organik Dan Serapannya Pada Tanaman Jagung. Agroekoteknologi, 1(3):479-488.

Nasr, A. H., M. Zare, O. Alizadeh and N. M. Naderi. 2013. Improving Effects of Mycorrhizal Symbiosis on Sorghum Bicolor Under Four Levels of Drought Stress. Agricultural Research, 8(43):5347-5353.

Nurbaity, A., D. Herdiyantoro dan O. Mulyani. 2009. Pemanfaatan Bahan Organik Sebagai Bahan Pembawa Inokulan Fungi Mikoriza Arbuskula. Biologi, 12(1):7-11.

Nurhalimah, S., S. Nurhatika dan A. Muhibbuddin. 2014. Eksplorasi Mikoriza Vesikular Arbuskular (MVA) Indigenous pada Tanah Regosol di Pamekasan, Madura. Sains dan Seni Pomits, 3(1):30-34.

Othira, J. O., J. O. Omolo, F. N. Wachira and L. A. Onek. 2012. Effectiveness of Arbuscular Mycorrhizal Fungi in Protection of Maize (Zea mays L.) Against Witchweed (Striga hermonthica Del Benth) Infestation. Agricultural Biotechnology and Sustainable Development, 4(3):37-44.

Pambudi, D., M. Indrawan dan Soemarno. 2017. Pengaruh Blotong, Abu Ketel, Kompos Terhadap Ketersediaan Fosfor Tanah Dan Pertumbuhan Tebu Di Lahan Tebu Pabrik Gula Kebon Agung, Malang. Tanah dan Sumberdaya Lahan, 4(1):431- 
443

Rajiman. 2014. Pengaruh Bahan Pembenah Tanah Di Lahan Pasir Pantai Terhadap Kualitas Tanah. Prosiding Seminar Nasional Lahan Suboptimal. 147-154.

Santi, L. P. 2016. Pengaruh Asam Humat terhadap Pertumbuhan Bibit Kakao (Theobroma cacao) dan Populasi Mikroorganisme didalam Tanah Humic Dystrudept. Tanah dan Iklim, 40(2):87-94.

Sirappa, M. P. 2003. Prospek Pengembangan Sorgum Di Indonesia Sebagai Komoditas Alternatif Untuk Pangan, Pakan, Dan Industri. Litbang pertanian, 22(4):133-140.

Suarni.2012. Potensi Sorgum sebagai Bahan Pangan Fungsional. Iptek Tanaman Pangan, 7(1):58-66.

Supari, Taufik, B. Gunawan. 2015. Analisa Kandungan Kimia Pupuk Organik Dari Blotong Tebu Limbah Dari Pabrik Gula Trangkil. Prosiding SNST ke-6.Fakultas Teknik Universitas Wahid Hasyim Semarang.

Tanzil, A. I., A. Muhibbudin dan S. Djauhari. 2015. Eksplorasi Fungi Tanah Pada Rizosfir Tomat Di Lahan Endemis Dan Non Endemis Fusarium oxysporum f. sp. Lycopersici. HPT, $3(1): 11-20$.

Victolika, H., Sarno dan Y. C. Ginting. 2014. Pengaruh Pemberian Asam Humat dan $\mathrm{K}$ terhadap Pertumbuhan dan Produksi Tanaman Tomat (Lycopersium escolentum Mill). Agrotek Tropika, 2(2):297-301. 